\title{
Introduction: Rethinking Colonialism and Indigenous Sovereignty
}

\author{
Pekka Hämäläinen \\ University of Oxford, Oxford, United Kingdom \\ pekka.hamalainen@history.ox.ac.uk
}

The essays of this roundtable refigure colonialism and Indigenous agency in early America, drawing from one another and complementing one another. They interrogate settler colonialism and its usefulness as an analytical category and its various and often contested meanings; they probe the concept from an Indigenous perspective, illuminating how Native peoples have resisted, evaded, navigated, and understood overseas colonialism. Together, the essays provide a nuanced comparative inquiry of Indigenous power, Indigenous sovereignty, and Indigenous survival in early America.

Animated by a quest to better understand the character of early America, Charles Prior calls attention to a multifaceted contest for sovereignty-between settlers and Natives, between settlers and imperial agents, and between Indians and imperial agents. Settlers clamored for Indigenous lands and wanted imperial agents to help them, whereas Indians wanted imperial agents to mobilize their laws to protect their sovereignty and lands. Prior abstracts these vectors as a "square" whose sides represent four forms of agency and power: metropolitan, settler, Indigenous, and colonial. Crucially, he does not conflate "settler" and "colonial," which allows him to reexamine how boundaries and sovereignty were conceived, contested, negotiated, won, and lost on the ground in early America.

This is a nuanced analytical template that is subtler than the now seemingly ubiquitous concept of "settler colonialism" allows. Historians are now reading settler colonialism somewhat indiscriminately into the past and into places and dynamics where it did not necessarily exist. Settler colonialism was conceived to explain the Australian condition where colonialism unfolded mostly outside of the British Empire and beyond an imperial bureaucracy. In Australia, settlers were the violent edge of empire. In North America, by contrast, the United States reinvented itself as what Steven Hahn calls "imperial 
nation-state" that relied on armies, forts, government agencies, treaties, reservations, and, more abstractly, shear bureaucratic prowess, to dispossess and control the continent's Indigenous inhabitants. Settler violence did contribute to the dispossession of Native peoples in North America, but it did not drive it. Settler colonialism was an upshot of successful colonization, of state-driven elimination of Indigenous populations, not its initiator.

Like Charles Prior, Heather Hatton focuses on what happened on the ground, examining how ideologies, principles, words, metaphors, and stories became Indigenous means to assert power, autonomy, and sovereignty against colonial pretensions. And like Prior, Hatton asks how Native peoples-in her case the Five Iroquois Nations - conceived, asserted, and guarded their sovereignty. Hatton invites us to revisit the Covenant Chain, which has traditionally been understood as a series of alliances and treaties between the Iroquois Confederacy and the British colonies. She asks us to consider the Covenant Chain as a metaphor for belonging, as a story with a powerful moral imperative, and as a narrative that reaffirmed Iroquois sovereignty against colonial and Indigenous rivals alike. For the Iroquois, she suggests, the past and the present were inseparable, an unbroken continuum that underwrote their sovereignty indefinitely. When Iroquois re-counted stories of the past in diplomatic meetings, they were making demands to the colonists and instructing them how to behave and how to think. They were doing what historians have assumed was the colonists' prerogative: telling others how to be in the world. That kind of revisionist approach to colonial America - rethinking expected historical roles and the arrows of influence and power - is now challenging the very nature of the field. 